\title{
Minding their Ps and Qs; the Royal Navy purser and accounting and governance, $1731-1808$
}

\author{
Karen Mcbride, \\ University of Portsmouth
}

\begin{abstract}
This paper explores the accounting regulations imposed on sea officers, particularly the purser, on board Royal Navy ships between 1731 and 1808. This was a period in which the Royal Navy grew to become one of the largest enterprises in Europe with operations throughout the world. The governance, control and accountability practices imposed upon pursers are analysed. The Regulations for accounting records to be kept by pursers indicate that accounting changed very little in the analysis period, until 1808, when it became substantially more detailed. Drawing on institutional theory, it is argued that this was due to external pressures for increased governance following the impeachment of Melville (First Lord of the Admiralty), public spending administrative and accounting reforms and political disapproval of 'offices of profit'. The paper provides important insights to the development of accounting, governance, audit and accountability within the Royal Navy, and enhances understanding of the historically unique role of pursers.
\end{abstract}


Key words: accounting, governance, accountability, control, audit, Institutional Theory, Purser, Royal Navy 


\section{Introduction}

This paper ${ }^{\mathrm{i}}$ contributes to a broader understanding of accounting and governance reforms in the Royal Navy (hereafter the Navy) by examining the "Regulations and Instructions relating to His Majesty’s Service at Sea" (hereafter Regulations) issued to sea officersii. Particular attention is applied to our analysis of the Regulations pertaining to pursers. The intent is to provide a critical explanation of when and why those Regulations changed and to set them in a historical context. Just as current financial crises provide a catalyst for reforms in governance and accounting, so in history, external, political and financial pressures affected the governance of accounting in the Navy. This paper is a response to calls (for example, by Bisman, 2012) for the role of accounting histories to explore the how and why of accounting change and to disentangle and detail "the nature and process of change itself" (Bisman, 2012: 16) whether that be by a single event or many contributing events.

The focus of this paper is the Regulations issued between 1731 and 1808. In this period, the Navy grew to become one of the largest enterprises in Europe (Rodger, 2004: 41). It was also a period of major government introspection and rethinking, prompted by the shock of defeat in the American War (Knight, 2008). The Navy had increased in size due to the worldwide conflict with France. That fighting started in 1690 and ended with the Napoleonic Wars ${ }^{\mathrm{iii}}$. This was a period when battle at sea became fully developed. The Glorious Revolution (1688) changed the political map within Europe and this resulted in a succession of wars with France that endured for more than a century and substantially increased the battle skills of the Navy. Military finances were concentrated in the Navy. This enabled Britain to defend its lands and to pressure the trade routes of rival countries, making its power felt across the seas. During the French Revolutionary Wars (1793-1802) and the Napoleonic Wars (1803-1815) the Navy was at the height of its efficiency, setting a benchmark for other European navies. 
When the American War (1775-1783) commenced, the Navy captured or destroyed many ships. However, France fought with America and this led to Britain's loss of the North American colonies. There were financial pressures on the funding of the Navy as a huge sum of money had been spent financing this warfare. The national debt substantially increased, leading to increased taxes. Britain's wealth, generated by trade, was also affected. Imports and exports were interrupted, leading to a recession and the falling of stock and land prices (MacDougall, 2013).

The Committee on the Public Accounts was established in 1780 and was the forerunner of administrative reforms during the next half century (Torrance, 1978). Indeed, the measures by which government had been assessed for most of the $18^{\text {th }}$ century changed after 1782 . What had been accepted as government practice previously (e.g. sinecures or offices of profit) was no longer tolerated. Higher expectations of public behaviour, such as responsibility and honesty, influenced new practices and governance (Baker, 1973). A further contribution of the paper is to broaden the understanding of the impact of external political and governmental pressures on the internal workings of the Navy and its efforts to seek and maintain legitimacy thereby shoring up government support through continued funding.

The "Regulations and Instructions relating to His Majesty's Service at Sea" of 1731 through to 1808 (hereafter 1731 or 1808 Regulations) were issued by the Admiralty for the control of sea officers and materials, including provisions. The accounting and governance of the Navy had remained relatively unchanged since the first Regulations in 1731, until a redrafting was instituted in 1806 and implemented in 1808. The paper also highlights the role of key participants in the changes of the Regulations requirements.

This study of accounting and governance is concerned with understanding the development of record-keeping and accountability in the Navy. Brammer et al. (2012) contend it is often forgotten that understanding an institution is linked with history and that processes of 
institutional change are a consequence of historical negotiations of prevalent rules and conventions (Thelen, 1999). Institutions tend to replicate the influences and power relationships at any point in time. Once established, the ways in which an organisation functions remain the same for long periods of time. This was the case in the Navy. The Regulations remained in force with only minor changes for almost a century (1731 to 1808). The Regulations were reworked following the impeachment of Viscount Melville (Treasurer of the Navy, later First Lord of the Admiralty) in $1806^{\mathrm{v}}$ and because of the need to retain and seek further external funding from Government. The Navy depended on government funding, however, questions had been raised in Parliament as to the legitimate use of this funding. The Government was committed to discontinue practices of patronage, offices of profit and to seek out misuses of finances (Hamilton, 2011). The changes in accounting reflect these influences.

This paper investigates the changes made to the Regulations that had a major impact on the accounting procedures required from pursers. As on-board accountants, pursers were also ships' store-keepers responsible for provisioning seamen with rations and slops (clothes) ${ }^{\mathrm{vi}}$. During the period studied, the purser's status improved: in 1807 he received a uniform and as a warrant officer he was granted wardroom status (Rodger, 2004), a privilege usually reserved for commissioned officers.

The analysis here is confined to the Regulations governing pursers in the Navy, in the period 1731 to 1808 . The focus is on the purser's role in provisioning and issuing stores, and in the associated accounting. The paper explores the accounting-related roles, and the accounting, governance and auditing controls that were part of the purser's duties. Naval historians (Rodger, 1986; MacDonald, 2004; Lewis, 1960) have explored victualing of ships, the administration and provisioning of supplies on board and the way pursers performed their duties. These explanations are extended here by considering the related governance, accounting controls and procedures. McBride and Hines (2018) suggest that the Regulations 
were designed for control of costs and protection of provisions for the well-being of a ship's crew. This paper argues that governance increased in response to social expectations, resulting in increased accounting requirements.

The structure of the paper is as follows. The next section presents a literature review and develops a theoretical framework that draws on institutional theory and its links with legitimacy. Then an explanation of the research method follows, and the archival sources used. A discussion of the Regulations ensues, followed by the purser's role and accounting instructions. The analysis is conducted using institutional theory, under the sub-headings, "Responding to social expectations", "Establishing legitimacy", "Establishing and maintaining legitimacy", and "Adoption and influence of practices". This is followed by a summary and conclusions. Some recommendations for further research are offered in the final section.

\section{Literature review and theoretical framework}

Naval and other military accounting research

In accounting history research, there is a small but growing literature studying British military history (Walker, 2005). Calls for further research in the area of military history (Chwastiak and Funnell, 2010) have been answered. Indeed, accounting for the military, and for wartime activity as a subset of accounting history is thriving (Cobbin and Burrows, 2018). This paper adds to the literature by developing an under-explored area within that subset, that of naval accounting.

Prior studies of naval accounting practices have explored the ancestries and usage of practices and procedures in naval settings that are the foundations of current day accounting (Scorgie and Reiss, 1997). Nascent forms of standard costing and accounting control of materials waste before the British Industrial Revolution were investigated in a study of the purser's measure (McBride et al., 2016). Rosier (2010) identified cost recording for ship 
building within the Royal Dockyards and private dockyards in the $18^{\text {th }}$ century. Budgetary reforms in naval reporting in the $19^{\text {th }}$ century have been studied by Cobbin and Burrows (2010). The influence of the federal expenditure control system on an individual, a Navy Agent in 1861-1864 has been considered by Mayer-Sommer (2010). However, none of these papers have investigated broadly accounting and governance in the Navy.

In the closely related area of army accounting and costing, research papers have investigated the influence of army procedures on the development of accounting (Hoskin and Macve, 1988; 1994). The development of accounting and costing within the army has been explored by Black, 2001; Bowlin and Herda, 2015; Funnell, 2003, 2005, 2006, 2009; and Talbot, 2000, 2010, as has budgeting and measuring of efficiency (Cobbin, 2009; Funnell, 2011) Research has considered the roles of everyday men and women, soldiers and civil servants involved with military accounting (Black, 2006a; 2006b; Black, 2015; Black and Edwards, 2016). This stream of research includes studies of the development of management accounting and innovations in various military organisations, for example, military hospitals (Sanchez-Matamoros, 2014; Sanchez-Matamoros and Funnell, 2015). Most literature in this area focusses on costing, accounting practices and the enhancement of efficiency (Cobbin and Burrows, 2018), improvements that may have been intended to send the right signals of legitimacy in order to secure future funding, but this aspect has not been explored in-depth within the literature.

Studies of the influence of wars is a major focus of many papers addressing military accounting history (Funnell and Chwastiak, 2015). A focus on cost accounting practices of the U.S. Army during the American Civil War have illustrated the contribution to modern cost accounting (Previts and Merino, 1998; Vollmers et al. 2016; others outlined in King et al., 2009). The politics of military finance during war have been analysed (Funnell, 2006; Funnell, 2010; Funnell and Chwastiak, 2015; Heier, 2010). The supplying of military equipment in 
World Wars (WWs) I and II have been investigated by Miley and Read (2014 and 2012). Indeed, both WWs have been the time frame for studies in accounting practices and costing. WWI literature (Antonelli et al., 2014; Arnold, 2014; Billings and Oats, 2014; Cardoni, 2014; Flescher and Previtts, 2014; Miley and Read, 2017; Quinn and Jackson, 2014; Rutterford and Walton, 2014) considering accounting's evolution to achieve the needs of war, or contributing to the war, or war influencing accounting. Similarly in WWII (Cinquini et al., 2016; Djateji and Sarikas, 2009; Fleischman and Marquette, 2003; Ikin et al., 2012; Lippman and Wilson, 2007) with war having an influence on accounting or changes in accounting to meet the needs of war. The impact of the relationship between the military and the government on accounting is explored by Funnell (1997) and Bujaki (2010; 2015). Lai et al. (2012) explain accounting’s use for rational decision making in military and political agendas. The preponderance of literature in military accounting has focussed on war or the requirements of the military in driving accounting developments and new accounting knowledge. This paper considers the environment where the support to military functions between wars should be justified, with the need to justify continued funding acting as a force to improve accounting.

This research focuses on institutional accounting change (or stability), assesses the increase of governance and accounting procedures to illustrate that public finances were being expended legitimately for the Navy in a time of post-war financial crisis to legitimise the financing for future wars.

\section{Institutional theory}

An institutional perspective is used to explain how accounting in the Navy was revised and modified in 1806 in response to external pressures for enhanced accountability and increased governance ${ }^{\mathrm{vii}}$. Mason et al. (2007) suggest institutional analysis as a good means of considering governance of organisations. Institutional theory acknowledges that organisations 
"exist in an institutional environment that defines and delimits social reality" (Scott, 1987: 507). Organisations need to mould to the social expectations that are part of their social environment (Fogarty, 1992). These social environments include prevalent norms, rules, values, ideas and expectations (Scott, 2008).

Fogarty (1992) advocates the use of institutional theory to explain why organisations need to seek and attain social approval in response to social expectations. Organisations operate in such a way as to appear to accommodate these social expectations (Fogarty et al. 1997). Failure to do this may threaten, for example, their ability to self-regulate (Fogarty, 1996). Indeed, institutional theory highlights the forces causing processes of institutional change and the value of a strategy of institutional conformity by the organisations (i.e. to follow external standards or norms, see DiMaggio and Powell, 1983; Meyer and Rowan, 1977). A public organisation such as the Navy, needs to respond to social expectations by maintaining and managing legitimacy with external groups, in particular with the Government, to retain support and funding. This is explored in the section "Responding to social expectations" which analyse the response of the Navy to the revised Regulations, the prevalent norms, values and ideas implemented for implicit social approval.

Organisational legitimacy is a primary idea in institutional theory. The idea has been used by accounting academics (e.g. Hines et al., 2001; Georgiou and Jack, 2011) and is relevant to this research. Legitimacy in institutional theory (e.g. DiMaggio and Powell, 1983; Meyer and Rowan, 1991; Meyer and Scott, 1983; Powell and DiMaggio, 1991; Zucker, 1977) considers the environment of the organisation and its institutional forces. These are conceived as causing social, economic, political and cultural forces that are beyond the control of the individual organisation (Suchman, 1995). Legitimacy is established and needs to be maintained by the organisation in its environment, to ensure the organisational survival. Fogarty et al. (1997) observed that an organisation which does not comprehend the need to show engagement 
with the prevailing values of the social environment, is in the danger of losing support and possibly, its existence. Long-standing state agencies such as the Navy, need to maintain legitimacy by showing that governance procedures comply with institutional expectations (Bealing 1994; Bealing et al., 1996). They also need to communicate the rationality of the processes of governance to various stakeholders (Rollins and Bremser, 1997).

However, whilst the notion of survival or threatened existence are a logical consequence of attaining or not achieving legitimacy, as articulated within institutional theory, care needs to be taken in applying the theory to an organisation such as the Navy. During the $18^{\text {th }}$ and $19^{\text {th }}$ century, the Navy was central to British national survival, security, growth and economic progress. Therefore, a contention that its existence may have been threatened in a similar manner to other government agencies, corporations or other entities may seem exaggerated, particularly with hindsight. The Navy effectively operated in a dispersed manner, protecting the country and the British Empire as it grew. After Melville's 1806 impeachment however, there was closer attention to the Navy finances and although the Navy was not under threat as an organisation, legitimacy was still crucial for it to compete successfully with other government agencies for funding. The paper considers this in the section "Establishing and maintaining legitimacy": the Navy was aiming to maintain financial support by the outward appearance of rationality and accountability

DiMaggio and Powell (1983) point out that to illustrate rationality and accountability, organisations conform to their institutional environment. DiMaggio (1988) clarifies the selfregulating and often ingenious ways in which organisations infuse and replicate their institutional environments. A governmental agency's credibility is endangered when the support of key power groups is not maintained (Mezias, 1990). Political communications such as the conformance to the Regulations for the Navy may be made to external parties (e.g. the British government) in order to legitimate an organisation (Bealing et al., 1996). Thus, 
organisations engage with the social expectations of their external parties. Organisations can also develop behaviours that are more representative than practical. Their actions may meet the demands of their operating environment, while being of little use in practical terms or uneconomic. The greatly expanded Regulations for the Navy from 1808 were verbose and detailed, requiring many more certificates, vouchers and forms. Whilst the enforcement of these requirements in the Navy were meant to increase governance and met external expectations, or appeared to do so, they may not have been efficient in practice, for the Navy itself.

Internal systems are often complicated, they can be difficult to explain, and they could be subservient to the issue of external legitimacy (Meyer, 1986). Fogarty et al. (1997) develop this argument, affirming institutional theory's contention that the actual achievements of the organisation and those suggested by its structure are often different. If appropriate structures are adopted, organisations may escape scrutiny by external observers (Fogarty, 1996). The changes in Navy governance explored here did not seek to achieve economic results, despite higher control over allocation of provisions was a major objective of governance procedures. Nonetheless, institutional theory offers a means of understanding the motivations behind the implementation of the new Regulations. These ideas are considered in the section of the paper which considers whether practices were adopted and whether these increased efficiency, as there may be the appearance of benefits, but the practices adopted will not necessarily improve performance.

The analysis in this paper considers governance in the Navy using these main tenets of institutional theory for framing the following sections: "Responding to social expectations", "Establishing and maintaining legitimacy", and "Adoption and influence of practices".

\section{Research Method}


This research is based on primary sources located at Portsmouth Naval Dockyard, the National Archives at Kew and the Caird Library at Greenwich in the UK. Additional secondary sources are used mostly for contextualisation. Archives are defined here to include Regulations and Instructions issued to the Navy, accounting records, and other subsidiary and source documents, such as Navy correspondence. The study thereby uses a broad interpretation of accounting and governance, moving beyond the numbers to include the documents that form the basis of the records. Triangulation has been used wherever feasible on the data to strengthen the rigour of the basis for the research findings.

The Regulations stored in the archives were analysed. The analytical approach involved transcribing the 1734 copy of the Regulations (no real change from the originals in 1731), those of 1790 (with some additional requirements added at the end) and the 1808 rewritten version, in order to compare them. Themes identified were informed and underpinned by institutional theory. A table included in Appendix 1 provides evidence of the changes by matching the sections from the original Regulations to the 1808 version and showing the number of new words and forms required.

The methodological approach combines elements of traditional and new accounting history. It is based in archival sources but follows the approach of new accounting historians who highlight the need to analyse historical events and actors in their specific political, organisational and socio-economic contexts (Bryer, 1993; Carnegie, 2004; Carnegie and Napier, 2002; Gomes, 2008). The research is "grounded firmly in the archive while being informed by theoretical perspectives" (Carnegie and Napier, 1996: 31) seeing history as useful and being aware that stability and change are the important contribution of historical research in accounting (Carnegie and Napier, 2012).

\section{The Regulations}


The primary archival resource used in this study are the Regulations, first issued in 1731. These were used to form the 1734 Regulations, which were reissued in a slightly adjusted form at various times in the following years, with amendments added as "Additional Instructions". A substantially rewritten version was issued in the 1808 edition. The study conducted here examines this change period (1790 and 1808 Regulations) to illustrate the increase in control and governance of the Navy.

\section{Responding to social expectations}

The 1731 Regulations were issued to standardise control over ships officers and to clarify orders (Dickinson, 2007). This document, drawn up by Thomas Corbett, Deputy Secretary of the Navy (Baugh, 1977), was organised and structured, and showed the duties of the various officers. It provided instructions for commissioned and warrant officers, including pursers, with details of the accounting required for issuing and controlling provisions. The Regulations gave examples of the eight forms required for accounting. In the following 77 years, the Regulations were reissued 13 times. The 1808 redrafting was preoccupied with governance and control, effected mainly through additional accounting requirements.

Between the 1731 and the 1790 editions, the Regulations changed very little. The rewriting mainly refined previous versions. In the edition of 1790 , the requirements for accounting are like those of the 1731 Regulations. However, the 1808 Regulations were greatly expanded, with a substantial increase in accounting procedures (Lavery, 1998). This last edition analysed attempted to increase uniformity in the day-to-day functioning of the Navy and increase governance and accountability of officers to the Admiralty ${ }^{\text {viii }}$. The failure in the American War had resulted in government administrative reforms. The Committee on the Public Accounts had revealed inadequacies in the Navy, which the Navy now sought to 
address. Melville's impeachment in 1806 was a public embarrassment for the Navy (Longman, 1806).

There was very little influence from King George III or the Parliament in the administration of the Navy (Hamilton, 2011). However, during the 1780s the Comptroller of the Navy, Rear Admiral Charles Middleton had worked with the Prime Minister, William Pitt the Younger, and was enthusiastic about the latter governance reforms (Wilson, 2013). After Melville's impeachment, there was increased external political pressure on the Navy to show improved financial diligence. Under Pitt the Younger, parliamentary reforms had increased governance and control of public finances (Turner, 2003). In support of these reforms, both professionalism and bureaucracy increased. The Navy needed to conform to this new environment of increased professionalism and bureaucracy to meet social expectations. Middleton (who became Lord Barham) succeeded Melville as First Lord of the Admiralty in 1805 and, in 1806, drafted the greatly expanded 1808 edition of the Regulations (Blake, 2014).

\section{Establishing legitimacy}

The Regulations represented Middleton's response to these wider criticisms of the Navy and its working. The 1808 Regulations increased to 683 pages from 237 pages in 1790 . The fact that the Regulations $(1790,1808)$ were "established by his Majesty in council" (front page) sent signals of legitimacy to the key power groups in order to retain their support.

\section{The purser's role and accounting instructions}

Establishing and maintaining legitimacy 
To explore the detail of the Regulations issued, and to determine how they helped to establish and maintain legitimacy, the Regulations pertaining to the purser have been examined.

Pursers' "primary duties were the receiving, issuing and accounting for provisions" (Baugh, 1965: 394). In 1665, Samuel Pepys (Clerk of the Acts of the Navy Board) ${ }^{\text {ix }}$ proposed that there should be a central Surveyor General of Victualling for HM (His Majesty's) Navy (Diary, 14 October 1665). Pepys occupied this post (Diary, 19 October 1665), heralding the start of upgraded governance and control of provisions. The "Duke of York's Orders and Instructions" issued in $1662^{\mathrm{x}}$ gave clear indications over the initial duties expected of pursers. However, there was very little detailed instructions regarding accounting or governance of the internal administration of naval ships.

The 1731 Regulations provided instructions on many matters, including victualling (Warlow, 1984). These were mainly a summary of past orders designed to control officers' actions through the accounting (Rodger, 2004). Pursers became responsible for keeping more detailed accounts (Claxton, 1837) and, at the same time, their education and professionalism improved (Dickinson, 2007). At the time of "Nelson's Navy" (1793-1815), a purser "served a year as a captain's clerk", did not "keep watch"; and on larger ships "had a steward" (Blake and Lawrence, 2005: 70). He was also responsible for keeping the muster rolls of crew on which the payment of wages depended (Brock, 1986).

The purser issued the victuals or provisions to sailors and was accountable for the stores issued to him by the Victualling Board. The storekeeper, at the victualling yard, kept his own accounts. These provided a "cross check" confirmation of the pursers' accounts ${ }^{\mathrm{xi}}$ (Appendix 2). A purser could spend large amounts of money in advance in the hope of future returns. Invariably, he was required to obtain favourable credit to finance these activities (Rodger, 1986). 
The purser's main role was to ensure his ship was provisioned to the appropriate standards and levels. These were calculated based on the size of the ship (its rate, or class) and the length of time the rations were expected to last. The level of rations, determined in 1731, did not change until the following century. The bulk of provisions were provided through the dockyards, through contracts negotiated by the Victualling Board (Knight and Wilcox, 2010). The provisions, and the bags or casks containing them, were charged to the purser's account (Purser's Instructions, 1739).

The 1790 Regulations (Article 1) clarify the role of the purser:

"The purser, being the officer who is entrusted with keeping and distributing the provisions out to the ship's company, is to observe the following Instructions" (p. 115).

The equivalent Article 1 in the 1808 Regulations is much longer, more verbose but clearly requiring governance, control and detailed accounting:

"The purser is the officer entrusted to receive the provisions and victualling stores, to keep and distribute the same to the ship's company, and, upon particular and urgent occasions, to purchase and provide, and finally to account for the same. [The purser acts] with two proper and competent persons as his securities for the due discharge of his trust, [he has to] enter into a bond with His Majesty for a penal sum established according to the rate or class of the ship or vessel to which he may belong, as undermentioned, viz ${ }^{\mathrm{xii}}$. general duty of the purser.

To give security for the discharge of his trust.

$£$

$1^{\text {st }}$ rate $\quad 1200$

$2^{\text {nd }}$ ditto $\quad 1000$

$3^{\text {rd }}$ ditto $\quad 800$ 


$\begin{array}{ll}4^{\text {th }} \text { ditto } & 600 \\ 5^{\text {th }} \text { ditto } & 600 \\ 6^{\text {th }} \text { ditto } & 400 \\ \text { and sloops, \&c. }\end{array}$

He is hereby strictly required and directed to observe and abide by the following Regulations, Stipulations, and Instructions; and he is not to expect that any irregularity in or omission of any part thereof, or of the Forms referred to therein for keeping his accounts, will be overlooked" (p. 317).

All sets of Regulations required the purser to "inform himself", to be aware of when the ship should be victualled and to ensure all the necessary rations were on board. There was also a requirement that the provisions should be "sweet" and "good" (1790 Regulations: 116; Mountaine, 1690: 194), “and wholesome”, in the 1808 Regulations (1808 Regulations: 318; Commissioners for Executing the Office of Lord High Admiral of the United Kingdom of Great Britain and Ireland (CEO, 1825). In the original instructions, the purser was required to note the marks on any casks so that, should they be found defective, he would be able to testify as to their source. Again, there is an increase in governance in the latter Regulations. The onus passed to the purser to ensure all the casks were sound or otherwise to object (1808 Regulations: 318).

The 1808 Regulations used tables to illustrate allowances. Four additional tables were included. One table detailed, in addition to the purser and his servant's wages, an allowance "for encouraging him to a zealous and faithful discharge of his duty" (p. 318) in completing his accounts. The accounts were passed to the Victualling Office and showed the amounts for which he was a creditor. There was a table of allowances for this as represented in Table $1^{\text {xiii }}$.

$£ \quad$ s. $\quad$ d.

$\begin{array}{llll}0 & 0 & 13 / 4 & \text { per pound }\end{array}$ 


$\begin{array}{lllll}\text { Beer } & 0 & 0 & 13 / 4 & \text { per gallon } \\ \text { Beef } & 0 & 1 & 8 & \text { per piece of } 81 \mathrm{~b} \\ \text { Pork } & 0 & 1 & 3 & \text { per piece of } 41 \mathrm{~b} \\ \text { Pease } & 0 & 4 & 0 & \text { per bushel } \\ \text { Oatmeal } & 0 & 0 & 6 & \text { per gallon } \\ \text { Sugar } & 0 & 0 & 4 & \text { per pound } \\ \text { Butter } & 0 & 0 & 6 & \text { per pound } \\ \text { Cheese } & 0 & 0 & 3 & \text { per pound }\end{array}$

Table 1. Allowance for faithful discharge of purser's duty.

Source: 1808 Regulations: 319.

All Regulations prevented the purser from selling or to making undue (or excessive) use of any of the provisions or stores under his charge. The 1808 Regulations add a table (see Table 2) of repayment amounts for provisions or stores paid for abroad or at home.

$\begin{array}{lllll} & £ & \text { s. } & \text { d. } & \\ \text { Bread } & 0 & 0 & 41 / 2 & \text { per pound } \\ \text { Beer } & 0 & 0 & 6 & \text { per gallon } \\ \text { Beef } & 0 & 4 & 8 & \text { per piece of } 81 b \\ \text { Pork } & 0 & 3 & 6 & \text { ditto of } 41 \mathrm{lb} \\ \text { Pease } & 0 & 9 & 0 & \text { per bushel } \\ \text { Oatmeal } & 0 & 1 & 3 & \text { per gallon } \\ \text { Sugar } & 0 & 1 & 0 & \text { per pound } \\ \text { Butter } & 0 & 1 & 0 & \text { per pound } \\ \text { Cheese } & 0 & 0 & 6 & \text { per pound } \\ \text { Vinegar } & 0 & 2 & 0 & \text { per gallon }\end{array}$

Table 2. Prices to be paid if in debt of any species of provision.

Source: 1808 Regulations: 320.

There were additional monitoring or auditing style checks on the pursers' accounts. The 1790 Regulations required him to deliver his books and accounts within six months after the ship was paid off, and to produce an affidavit that the quantities were delivered on board ship, and that he did not receive any money or was not supplied with more provisions than charged. The 
1808 Regulations also required him to keep a book that detailed the numbers of men on board and to produce this, with his victualing accounts certified by the captain, along with a captain's warrant for victualing.

The 1808 Regulations include an additional chapter (Chapter 3: 310 - 316) titled "Of the payment for provisions, which may be saved by the ship's company out of their daily allowance, or become due to them by their being put on short allowance" (short allowance was issued when the vessel was in port). Again, this mandated detailed governance and accounting procedures for the purser.

\section{Adoption and influence of practices}

The 1808 Regulations (p. 324) provide a table of annual allowances to incentivise pursers to complete the accounts required by the Regulations. The allowance was paid based on the complement of men aboard ship, on the passing of a purser's accounts and producing the certificates required. Searches have been carried out of the National Archives, the Caird Library at Greenwich and the National Maritime Museum to find actual purser accounts. A full set of purser accounts have not been discovered in any of these archives, therefore it is not possible to observe the actual level of compliance with the instructions. However, the allowances outlined were designed to ensure accounts were completed correctly. Various guidance manuals and other documentation suggests that the Regulations were taken seriously by pursers and other officers. For example, William Mountaine's (1690, 1756, 1761, 1778) handbook or pocket reference, the "Seaman's vademecum" (Latin for "go with me") was published to guide seafarers in how to comply with the Regulations. It provided details of the accounts required from pursers. There are volumes of printed "Instructions" (CEO, 1759, 1813, 1825 ) and a volume of printed "Instructions to pursers". This latter volume outlines the extant Regulations and Instructions. By way of example, a copy of the "Instructions to pursers" was 
issued to Oliver King as purser of HMS Savage (dated 28 August 1759). This copy is annotated in the margins in a way that indicates he, at least, attempted to follow the Regulations (“Instructions to pursers", 1759).

Severe penalties were prescribed for incorrect accounts, indicating an expectation of compliance. In the 1790 Regulations, the purser is required to "be very careful not to sign any accounts, books, lists or tickets, before he has thoroughly informed himself of the truth [emphasis added] of every detail [emphasis added] contained in the same" (p. 130). The 1808 Regulations state more fulsomely, with explicit penalties:

"He is never to sign any accounts, books, lists, tickets, receipts or vouchers for provisions or victualling stores, before he has so thoroughly examined and considered them as to be satisfied of the truth and correctness of every particular contained therein ; and if at any time discovery shall be made, that he has signed, or knowingly suffered or procured others to sign, a collusive or false ticket, lists, voucher, or vouchers of any kind, be will be discharged from his employ as a purser, be deemed unfit ever to be entertained as an Officer in His Majesty's service, will absolutely forfeit all the wages due to himself and servant to the time of his dismission, together with all such sum or sums of money, benefit, advantage, or emolument, as might otherwise arise and become due and payable to him for tobacco or slops issued to the Ship's company, or on the balance of his victualling account, and will also be subject to such pains and penalties as a court martial may inflict upon him" (p. 329).

The Navy Board kept records or registers of precedents and exceptions for pursers' accounts, however only one book, albeit a large volume (National Archives Admiralty ADM 30/44), was required for the period from 1752 to 1800 . This suggests that there were very few exceptions over this long time period. The exceptions listed were generally the recording of waste, leakage or condemned provisions. The longest section of four pages is devoted to "Extra 
allowances for liquors" (pp. 30-34). Page 87 details that "pursers who were in debt on the balance of their accounts and yet had certificates granted in order to obtain their admiralty". There were five of these, including “... purser of the Arundel and Barbados was considerable in debt on the accounts, he went on voyage with Captain Cook as clerk of the Endeavour and on his return was appointed purser of the Iris; he was not allowed to receive any wages until the debts were made good". From this, it would appear that accounts were kept even when they showed debts for the pursers involved.

Whilst it is unclear whether the instructions for many additional forms and accounting requirements improved the allocation and recording of the costs and control of the provisions for seafarers, they certainly resulted in more work and delay. The "Forms of Books or Accounts referred to in the Preceding Instructions" (1790 Regulations: 165) increased from 28 in 1790 to 94 pages of forms in 1808 (see appendix 1). The pages relating to the purser and his accounts increased from 16 to 42 pages (see appendix 1). The accounting and additional completion of forms and certificates was costly and protracted. Indeed, in the case of the purser, accounts could take many years to pay, often due to the laborious cross-checking of transactions. The pursers could not receive their pay until the Victualing Board had certified that they had no debt (MacDonald, 2010; e.g. ADM C/722 16 May, 1809, Navy Board to Victualling Board).

Besides being more detailed, the 1808 Regulations use more formal language and demand more governance. This was a clear sign of legitimacy to those external to the Navy. For example, there are additional instructions: the purser is required "to keep a victualling book, and deliver the same into the Victualling Office for passing his accounts" (p. 326). There are clear and forthright instructions on how the numbers of men in his victualing book should agree with the ships mustering books (a requirement for a further stage of checking, or audit) and of how it should be certified by the captain. The 1808 Regulations emphasise the importance of governance and control. 


\section{Summary and conclusions}

This study of accounting and governance has focused on understanding the development of record keeping in the Navy from the first Regulations and Instructions in 1731 to the major change in the Regulations in 1808. Accounting development and change in the Navy was gradual until 1808. Substantially extended Regulations required significantly increased records to be kept. External events, expectations and the need to secure continued funding instigated this change in accounting and governance. Melville's impeachment in 1806 was a key event in the process driving change.

This accounting change is viewed through the lens of institutional theory, as a response to the expectations of the organisation's environment and a demonstration of legitimacy. Although the Navy's existence was not under threat, to secure the high levels of funding it had experienced in the past, it needed to show the legitimacy of its operations and control of expenditures through increased Regulations.

The development of governance and changes in accounting are seen in the context of political and other external pressures on the Navy, especially about finances and funding. The revision of the Regulations in 1806 provided an opportunity for the Navy to give an impression of a financially responsible organisation. The Regulations used additional accounting procedures to allay fears from critical political commentary on matters pertaining to financial misdemeanours, regulatory inefficacy and offices of profit. The Regulations sought to ensure adequate regulation to limit the need for future revisions.

With Melville's impeachment, there was an increased focus on the use of, and safeguarding external funding and finances provided to the Navy. In public organisations, this was a time when increased administration and bureaucracy demanded increased governance and professionalism. Institutional theory acknowledges that organisations need to conform to 
external or social expectations and establish and maintain an outward appearance of legitimacy by following prevailing norms, values and ideas in order to retain support (Fogarty, 1992, 1996, Di Maggio and Powell, 1983, Hines et al, 2001). The 1808 increase in governance via increased accounting procedures was an attempt to seek legitimacy and demonstrate that those in charge were safeguarding the finances. Regardless of the actual level of the funding made available to the Navy, the regulators demanded increased governance of finances, to ensure continued high levels of funding.

This investigation of the motivation for the reworking of the Regulations in 1806 also questions whether the new practices really improved efficiency and performance. With the introduction of more forms and stages, many of which did not appear to improve working practices. Studying governance and accounting in the Navy at this time involves understanding the mechanisms that had been set to regulate the accounting for provisions by the purser. Regulations for accounting provided those financing the Navy with the primary source of information about the performance of those managing the day-to-day affairs of the Navy.

The paper has assisted in extending understanding of the unique role of the purser in the $18^{\text {th }}$ and $19^{\text {th }}$ century Navy. The purser's role initially involved keeping basic records or accounts to ensure seafarers received correct provisions. This record-keeping developed and became a means of control and governance over the actions and expenses of supplies, as well as the issue of the supplies on board ships. Developments included the introduction of standard costs, the 'purser's pound', a measure to provide for waste (McBride et al., 2016) and further requirements for accounting records so that pursers could be reimbursed. The accounts required a rudimentary form of internal control. There was a requirement that they be signed by the captain, verifying the records signed and certified by the purser himself. A basic form of internal audit also existed as the accounts were to agree with Victualling Board records. The impact of the increased Regulations on pursers was a requirement for more accounting, more 
form filling, and more verification. The 1808 Regulations required accounting records to become more complicated and numerous in order to demonstrate fulfilment of the essential functions of recording, control and governance. Future research could consider the next stages of development of accounting in the Navy, for example the introduction of double entry bookkeeping, whether this was influenced by this quest for efficiency and performance in dayto-day activities which does not appear to have been addressed by these increased regulations. 


\section{References}

\section{Primary Sources}

ADM 7/827 The National Archives - Duke of York's Orders and Instructions (1660).

ADM 2/1733 Duke of York Orders and Instructions and letters 1662-1666.

ADM 7/639 Instructions for Admiralty Navy Board Officials 1660-1735.

ADM 7/971 Regulations and Instructions relating to his Majesty's Service at Sea (1808)

London: Privy Council.

ADM 30/44 Navy Board: Navy Pay Office Various Registers Precedents and Exceptions for Purser Accounts 1752-1800.

ADM 7/216 Instructions and Regulations for the Guidance of the Officers of the Victualling Establishments at Home 1807.

ADM 106/3086 Regulations and Instructions for Pursers of HM Ships and Vessels 1825.

ADM C/722 16 May, 1809, Correspondence Navy Board to Victualling Board.

AND 28 Greenwich - Duke of York's Orders and Instructions (1660).

Commissioners for Executing the Office of Lord High Admiral of the United Kingdom of Great Britain and Ireland (CEO) (1813) Additional Instructions to the Flag Officers, Captains, Commanders, Commanding Officers and Pursers of His Majesty's Navy, Relative to Books and Accounts. London: Royal Navy.

Commissioners for Executing the Office of Lord High Admiral of the United Kingdom of Great Britain and Ireland (CEO) (1759) Regulations and Instructions for Pursers of HM Vessels. London.

Commissioners for Executing the Office of Lord High Admiral of the United Kingdom of Great Britain and Ireland (CEO) (1825) Regulations and Instructions for Pursers of HM Vessels. London. 
The Diary of Samuel Pepys ed. H. Wheatley (10 volumes, 1893-9). For the online edition www.pepysdiary.com.

HC Deb $4^{\text {th }}$ July 1805 , Vol 5 cc737-8, Impeachment of Lord Melville.

HC Deb $27^{\text {th }}$ March 1806, Vol 6 cc557-9, Lords Sitting, Impeachment of Lord Melville.

House of Commons Parliamentary Papers Report from Committee Appointed to draw up Articles of Impeachment against Henry Lord Viscount Melville $4^{\text {th }}$ March 1806. London: Reports of Committees.

Instructions to Pursers, volume of printed pursers' instructions issued to Oliver King, Purser of HMS Savage in 1759, accessed at Portsmouth Naval Dockyard Library.

Longman (1806) The Trial by Impeachment of Henry Lord Viscount Melville for high crime and misdemeanors before the House of Peers in Westminster Hall, between the $29^{\text {th }}$ April and the $17^{\text {th }}$ May 1806 London: Longman, Hurst Rees and Orme.

Mountaine W (1690) The Seaman's Vade Mecum. London: W \& J Mount.

Mountaine W (1756) The Seaman's Vade-Mecum and defensive war by sea London; W \& J Mount.

Mountaine W (1761) The Seaman's Vade Mecum. London: W \& J Mount.

Mountaine W (1778) The Seaman's Vade Mecum. London: J Mount, T Page and W Mount.

Regulations and Instructions relating to his Majesty's Service at Sea (1731) London: Privy Council.

Regulations and Instructions relating to his Majesty's Service at Sea (1734) London: Privy Council.

Regulations and Instructions relating to his Majesty's Service at Sea (1757) London: Privy Council.

Regulations and Instructions relating to his Majesty's Service at Sea (1790) London: Privy Council. 
Regulations and Instructions relating to his Majesty's Service at Sea (1808) London: Privy Council.

Wheatley H (1896) The Diary of Samuel Pepys London: George Bell.

\section{Secondary Sources}

Antonelli V, D'Alessio R and Rossi R (2014) Budgetary practices in the Ministry of War and the Ministry of Munitions in Italy, 1915-1918. Accounting History Review 24(2-3): 139160.

Arnold A (2014) A paradise for profiteers? The importance of profits during the first World War. Accounting History Review 24(2-3): 61-81.

Baker N (1973) Changing attitudes towards Government in Eighteenth Century Britain. In: Whiteman A, Bromley J and Dickson P (eds) Statesmen, Scholars and Merchants; Essays in eighteenth century history. Oxford: Oxford University Press, pp203-19.

Baugh D (1965) British Naval Administration in the Age of Walpole. Princeton NJ: Princeton University Press.

Baugh D (1977) Naval Administration 1715-1750. London: Navy Records Society.

Bealing W (1994) Actions speak louder than words: An Institutional perspective on the Securities and Exchange Commission. Accounting, Organizations and Society 19(7): $555-567$.

Bealing W, Dirsmith M and Fogarty T (1996) Early regulatory actions by the SEC: An institutional theory perspective on the dramaturgy of political exchange. Accounting Organisations and Society 21(4): 317-338.

Billings M and Oats L (2014) Innovation and pragmatism in tax design: Excess profit duty in the UK during the first World War. Accounting History Review 24(2-3): 83-101. 
Bisman J (2012) Surveying the landscape: The first 15 years of Accounting History as an international journal. Accounting History 17(1): 5-34.

Black J (2001) Full circle: The cost accounting experiment in the British Army 1917-25 and the Corps of Military Accountants. Journal of the Society for Army Historical Research 79(318): 145-162.

Black J (2006a) Supermen and superwomen: The Army pay services and the first World War, 1914-1920. Journal of the Society for Army Historical Research 84: 268-280.

Black J (2006b) War, women and accounting: The pioneering role played by women in the Army Pay Department during the first World War. Accounting, Business \& Financial History 16(2): 195-218.

Black J (2015) 'The pen is mightier than the sword': Linking educational history and accounting history in shaping historical thought. Accounting History 20(1): 63-84.

Black J and Edwards J R (2016) Accounting careers traversing the separate spheres of business and government in Victorian Britain. Accounting History 21(2-3): 306-328.

Blake R (2014) Religion in the British Navy 1815 - 1879: Piety and Professionalism. Woodbridge: Boydell Press.

Blake N and Lawrence R (2005) The Illustrated Companion to Nelson's Navy. Mechanicsburg, PA: Stackpole Books.

Bowlin W and Herda D (2015) Regulatory, accounting and business practices concerning the Sutler at Fort Abercrombie, Dakota Territory. Accounting Historians Journal 42(1): $37-60$.

Brammer S, Jackson G and Matten D (2012) Corporate Social Responsibility and Institutional Theory: New Perspectives on private governance. Socio-Economic Review 10: 3-28. Brock R E (1986) John Copland - a Purser in Nelson's Navy from Wembley. London: Brock. 
Bryer RA (1993) Double-entry bookkeeping and the birth of capitalism: Accounting for the commercial revolution in medieval northern Italy. Critical Perspectives on Accounting 4(2): $113-140$.

Bujaki M (2010) Cost-benefit analysis in correspondence related to building the Rideau Canal. Accounting History 15(2): 229-251.

Bujaki M (2015) Visualizing the Rideau Canal through early budget estimates, 1823-1824. Accounting History 20(1): 43-62.

Cardoni F (2014) The 'science' of French public finances in the first World War. Accounting History Review 24(2-3): 119-138.

Carnegie G (2004) Re-examining the determinants of barter accounting in isolated communities in colonial societies. Accounting History 9(3): 73-87.

Carnegie G and Napier C (1996) Critical and interpretive histories: understanding accounting's present and future through its past. Accounting, Auditing \& Accountability Journal 9(3): 7-39.

Carnegie G and Napier C (2002) Exploring comparative international accounting history. Accounting, Auditing \& Accountability Journal 15(5): 689-718.

Carnegie G and Napier C (2012) Accounting's past, present and future: the unifying power of history. Accounting, Auditing \& Accountability Journal 25(2): 325-369.

Chwastiak M and Funnell W (2010) Accounting and the military: Editorial. Accounting History 15(2): 147-152.

Cinquini L, Giannetti R and Tenucci A (2016) The making of uniform cost in a war economy: The case of the Uniconti Commission in fascist Italy. Accounting History 21(4):445-471.

Claxton A B (1837) Foreign Miscellany. Army and Navy Chronicle. Washington, 28 September. 
Cobbin P (2009) 'The best brains of the public accounting world': The restricted membership of the Army Accountancy Advisory Panel, 1942-1945. The Accounting Historian's Journal 36(2): 1-29.

Cobbin P and Burrows G (2010) The British navy's 1888 budgetary reforms. Accounting History 15(2): 153-172.

Cobbin P and Burrows G (2018) The profession of arms and the profession of accounting numbers - Accounting, the military and war: A review. Accounting History 00(0):1-38.

Dickinson H (2007) Educating the Royal Navy, $18^{\text {th }}$ and $19^{\text {th }}$ Century Education for Officers, Naval Policy and History. London: Routledge.

DiMaggio P (1988) Interest and agency in institutional theory. In Zucker L (Ed.) Institutional patterns and culture: 3-32 Cambridge MA: Ballinger.

DiMaggio P and Powell W (1983) The Iron Cage Revisited: Institutional Isomorphism and Collective Rationality in Organizational Fields. American Sociological Review 48: $147-$ 160.

Djatei A and Saritas R (2009) The second World War and Soviet accounting. Accounting History 14(1-2): 35-54.

Fleischman R and Marquette R (2003) The impact of World War II on cost accounting at Sperry Corporation. Accounting Historians Journal 30(2): 67-104.

Flescher D and Previtts G (2014) Haskins \& Sells during the First World War and its aftermath. Accounting History Review 24(2-3): 211-225.

Fogarty T (1992) Financial Accounting Standard Setting as an institutionalized action field: Constraints, opportunities and dilemmas. Journal of Accounting and Public Policy 11: $331-355$

Fogarty T (1996) The imagery and reality of peer review in the US: Insights from institutional theory. Accounting Organizations and Society 21 (2/3): 243-267. 
Fogarty T, Zucca L, Meonske N and Kirch D (1997) Proactive practice review: A critical case study of accounting regulation that never was. Critical Perspectives on Accounting 8: 167-187.

Funnell W (1997) Military influences on the evolution of public sector audit and accounting 1830-1880. Accounting History 2(2): 9-29.

Funnell W (2003) Accounting for War: Financial Control of the British Army 1846-1899. NSW: Accounting and Finance Academic Press.

Funnell W (2005) Accounting on the frontline: Cost Accounting, military efficiency and the South African War. Accounting and Business Research 35(4): 307-326.

Funnell W (2006) National efficiency, military accounting and the business of war. Critical Perspectives on Accounting 17: 719-751.

Funnell W (2009) Military. In: Edwards J and Walker S (eds) Routledge Companion to Accounting History. London: Taylor \& Francis, pp.561-578.

Funnell W (2010) On his majesty's secret service: accounting for the secret service in a time of national peril 1782-1806. Accounting Historians Journal 37(1): 29-52.

Funnell W (2011) Social reform, military accounting and the pursuit of economy during the liberal apotheosis, 1906-1912. Accounting, Business and Financial History 21(1): 6993.

Funnell W and Chwastiak M (2015) Accounting at War: The Politics of Military Finance. London: Routledge.

Georgiou O and Jack L (2011) In pursuit of legitimacy: A history behind fair value accounting. British Accounting Review 43: 311-323.

Gomes D (2008) The interplay of conceptions of accounting and schools of thought in accounting history. Accounting History 13(4): 479-509. 
Hamilton C (2011) The Making of the Modern Admiralty: British Naval Policy Making, 18051927. Cambridge: Military Histories.

Heier I (2010) Accounting for the ravages of war: Corporate reporting at a troubled American railroad during the Civil War. Accounting History 15(2): 199-228.

Hines A, McBride K, Fearnley S and Brandt R (2001) We're off to see the wizard: an evaluation of directors' and auditors' experiences with the Financial Reporting Review Panel. Accounting, Auditing \& Accountability Journal 14(1): 53-84.

Hoskin K and Macve R (1988) The genesis of accountability: The West Point connection. Accounting Organizations and Society 13(1): 37-73.

Hoskin K and Macve R (1994) Re-appraising the genesis of managerialism: A re-examination of the role of accounting at the Springfield Armory 1815-45. Accounting, Auditing \& Accountability journal 6(2): 4-29.

Ikin C, Johns L and Hayes C (2012) Field, capital and habitus: An oral history of women in accounting in Australia during World War II. Accounting History 17(2): 175-192.

King D, Premo K and Case C (2009) Historical Influences on Modern Cost Accounting Practices. Academy of Accounting and Financial Studies Journal 13(4): 21-39.

Knight R (2008) Politics and Trust in Victualling the Navy, 1793-1815. The Mariners Mirror 94 (2):133-149.

Knight R and Wilcox M (2010) Sustaining the Fleet, 1793 - 1815, War, the British Navy and the Contractor State. Woodbridge, UK: Boydell Press.

Lai A, Leoni G and Stacchezzini R (2012) Governmentality rationales and calculative devices: The rejection of a seventeenth-century territorial barter proposed by the King of Spain. Accounting History 17(3-4): 369-392.

Lavery B (1998) Shipboard Life and Organisation 1731-1815. Aldershot: Ashgate.

Lewis M (1960) A Social History of the Navy 1793-1815. London: Allen and Unwin. 
Lippman E and Wilson P (2007) The culpability of accounting in perpetuating the holocaust. Accounting History 12(3): 283-303.

McBride K, Hines A and Craig R (2016) A Rum Deal: The Purser's measure and accounting control of materials in the Royal Navy, 1665-1832. Business History 58 (6): 925 - 946.

McBride K and Hines A (2018) What shall we do with the drunken sailor? Accounting and controls for Alcohol in the Royal Navy in the time of Nelson. In: Quinn M and Oliveira J (eds) Accounting for Alcohol: An Accounting History of Brewing, Distilling and Viniculture. London: Routledge. Chapter 9.

McBride K (2018) ‘And one man in his time plays many parts' - Samuel Pepys the accomptant. XIV Convegno Nazionale della Societa Italiana di Storia della Ragioneria Conference: Accounting History and Arts: Turin from http://www.symposium.it/eventi/2018/xivconvegno-nazionale-sisr

MacDonald J (2004) Feeding Nelson's Navy: The true story of food at sea in the Georgian Era. London: Chatham Publishing.

Macdonald J (2010) The British Navy's Victualling Board, 1793-1815, Management Competence and Incompetence. Woodbridge, UK: Boydell Press.

MacDougall P (2013) London and the Georgian Navy. Stroud: The History Press.

Mayer-Sommer A P (2010) So many controls; so little control: The case of Isaac Henderson, Navy Agent at New York, 1861-4. Accounting History 15(2): 173-198.

Mason C, Kirkbride J and Bryde D (2007) From stakeholders to institutions: the changing face of social enterprise governance theory. Management Decision 45(2): 284-301.

Meyer J (1986) Social environments and organizational accounting. Accounting, Organizations and Society 11: 345 - 356.

Meyer J and Rowan B (1977) Institutionalized Organizations: Formal Structure as Myth and Ceremony. American Journal of Sociology 83(2): 340 - 363. 
Meyer J and Rowan B (1991) Institutionalised Organisations: Formal Structure as Myth and Ceremony In: Powell $\mathrm{W}$ and DiMaggio $\mathrm{P}$ (eds) The New Institutionalism in Organisational Analysis. Chicago: Chicago University Press pp. 41-62.

Meyer J and Scott W (1983) Centralization and the legitimacy problems of local government.

In: J Meyer and W Scott (eds) Organisational environments: Ritual and rationality. Beverly Hills:Sage pp. 199-215.

Mezias S (1990) An Institutional Model of Organisational Practice: Financial Reporting at the Fortune 200. Administrative Science Quarterly 35: 431-457.

Miley F and Read A (2012) The implications of supply accounting deficiencies in the Australian Army during the Second World War. Accounting History Review 22 (1): 73 91.

Miley F and Read A (2014) Cartoons as alternative accounting: front-line supply in the First World War. Accounting History Review 24 (2-3): 161-189.

Miley F and Read A (2017) The purgatorial shadows of war: blame and shellshock pensions, 1914-1923. Accounting History 22(1): 5-28.

Powell W and DiMaggio P (1991) (eds) The New Institutionalism in Organisational Analysis Chicago: University of Chicago Press.

Previtts G and Merino B (1998) A History of Accountancy in the United States. Ohio: Ohio State University Press.

Quinn M and Jackson W (2014) Accounting for war risk: Management accounting change at Guinness during the First World War. Accounting History Review 24(2-3): 191-209. Rodger N (1986) The Wooden World - An Anatomy of the Georgian Navy. London: Norton. Rodger N (2004) The Command of the Ocean - A Naval History of Britain 1649-1815. London: Penguin Books \& National Maritime Museum.

Rollins T and Bremser W (1997) The SEC's enforcement actions against auditors: An auditor 
reputation and institutional theory perspective. Critical Perspectives on Accounting 8:191 - 206.

Rosier B (2010) The construction costs of eighteenth-century warships. Mariner's Mirror 96(2): 161-172.

Rutterford J and Walton P (2014) The war, taxation and the Blackpool Tower Company. Accounting History Review 24(2-3): 103-117.

Sanchez-Matamoros, J (2014) Management accounting and rationalisation in the Army: The case of Spanish Hospitals in the $18^{\text {th }}$ century. Revista de Contabiladad - Spanish Accounting Review 17(1): 71-77.

Sanchez-Matamoros, J and Funnell, W (2015) War or the business of God, Sacred mission, accounting and Spanish military hospitals in the $18^{\text {th }}$ century. Accounting, Auditing \& Accountability Journal 28(3): 434-459.

Scott W (1987) The adolescence of Institutional Theory. Administrative Science Quarterly 32: 493-511.

Scott W (2008) Institutions and organisations: Ideas and interests. Los Angeles: Sage.

Scorgie M and Reiss J (1997) The Impact of Naval Experience on Accounting in Colonial Australia from 1788 to 1792 . Accounting History 2(2): 53-76.

Suchman M (1995) Managing legitimacy; Strategic and Institutional approaches. Academy of Management Review 20(3): 571-610.

Talbot P (2000) Accounting for local management control in the late Victorian volunteer army. Journal of the Society for Army Historical Research 78: 115-123.

Talbot P (2010) Colonel William Henry Sykes: His contribution to statistical accounting. Accounting History 15(2): 253-276.

Thelen K (1999) Historical Institutionalism in Comparative Politics. American Review of Political Science 2: 369-404. 
Torrance J (1978) Social Class and Bureaucratic Innovation, the Commisssioners for examining the Public Accounts 1780-1787 Past and Present 78: 56-81.

Turner M (2003) Pitt the Younger: A Life. London: Hambledon and London.

Vollmers G, Antonelli, V, D’Alessio R and Rossi R (2016) Cost Accounting for War: Contracting Procedures and Cost-plus Pricing in WWI Industrial Mobilization in Italy. European Accounting Review 25(4): 735-769.

Walker S (2005) Accounting in History. Accounting Historians Journal 32(2): 233-259.

Warlow B (1984) The Pusser and His Men: A Short History of the Supply and Secretariat Branch of the Royal Navy. London: B Warlow.

Wilson B (2013) Empire of the deep: The rise and fall of the British Navy. London: Hatchette UK.

Zucker L (1977) The role of institutionalisation in cultural persistence. American Sociological Review 42: 726-43.

Zucker L (1987) Institutional theories of organization. Annual Review of Sociology 13: 443464. 
Appendix 1.

Differences in Regulations and Instructions

[Insert table here] 
Appendix 2. List of Accounts the Purser had to submit to the Victualling Board.

Orders and Reports of Survey on:

○ condemned provisions;

o beer leakages;

○ for commencement of accounts;

Orders and receipts for:

$\circ$ on remains at the close of the account.

- provisions lent / supplied to ships of war;

- coals supplied to carpenter for extra services;

Certificates of:

- butter, hides, buckets supplied to boatswain;

- extra issues of wine.

$\checkmark$ supernumeraries or prisoners victualled but not installed in Victualling book;

$\checkmark$ stores lost by accident, thrown overboard, embezzled;

$\checkmark$ convoy lights, top and poop lights;

$\checkmark$ certified account of tobacco and soap issued.

Receipts for returns into store:

- account for short content of beef / pork with certificate;

- account of extra expense of casks, staves and hoops;

- current account of provisions purchased and savings paid for with all required vouchers and affidavit;

- general account of lemon juice and sugar received and expended;

- general account of live cattle and sheep received and slaughtered;

- number and content of the books;

- Victualling book;

- general account of provisions received and returned with affidavit;

- general statement of account;

- paper containing purser's calculation of provisions, necessary money, waste of casks, hoops and bags;

- Sick book when the commander of the Ship is the purser.

Source: ADM 106/3086. 


\title{
Endnotes
}

\begin{abstract}
'The expression "Minding your Ps and Qs" is believed to have originated from this time. Seafarers, who were often illiterate, would drink in local taverns on credit until payday. The barkeeper would keep an account of pints (Ps) and quarts (Qs) consumed, for the seafarer to settle when paid. Governance was required. The seafarer would need to mind his Ps and Qs or get into trouble with his finances.
\end{abstract}

ii The sea officers to whom the Regulations and Instructions were issued were as follows: the Flag Officer/ Commander in Chief and the Captain/ Commander in the first section, then the Lieutenant, the Master, the Boatswain and Master Sailmaker, the Gunner and Gunsmith, the Carpenter, the Purser, the Surgeon, the Master at Arms and the Corporal, the Schoolmaster and the Cook. Regulations were issued from 1731.

iii The fighting with France was indeed global, as it took place not only throughout Europe and the surrounding seas, but also in America and India. Some consider it the first world war.

${ }^{\text {iv }}$ In the Glorious Revolution, King James II of England was replaced by William III, Prince of Orange (his Dutch son-in-law and nephew) and his protestant daughter Mary.

${ }^{v}$ Viscount Melville (Henry Dundas) was Treasurer of the Navy between 1782 and 1800, and then First Lord of the Admiralty from May 1804 until May 1805. A parliamentary commission of enquiry appointed in 1802 resulted in his impeachment in 1806 on ten charges of misappropriation of public money. The hearing ended in a finding of formal negligence and an acquittal (this was the last British impeachment). Melville was acquitted on all charges, some with very small majorities. This combined with his unhelpfulness at the trial, led to public criticisms. Melville never held Naval office again (House of Commons, 1806; HC Deb, 1805; HC Deb, 1806).

${ }^{\text {vi }}$ For more detail on the purser's role, related standard costs and the purser's pound see McBride et al. (2016).

vii The term Governance is used in the context of accounting regulation and governance, including the development of regulatory frameworks, codes and guidelines.

viii The Admiralty secured funding for all aspects of naval activity, including ships at sea, the focus here. Whilst the Navy was the institution responsible for maintaining the ships, whether abroad, in home ports or in dockyards, it was the Admiralty that were particularly concerned with legitimacy, it was them who had to secure the ongoing support of government (through Parliament) and ensure funding. The Navy Board was responsible for the day to day civil administration of the Navy and allocated the funds to various areas including the ships. Admiralty were the principals and the Navy, the Navy Board and all the operatives the agents. Officers within the Navy such as pursers were the individuals on board ship, who were the means by which this accountability was delivered and demonstrated. 
ix Samuel Pepys became Clerk of Acts in 1660, he was responsible for organisation of the Navy Office. This role involved processing naval contracts and the secretarial work of the Navy Board (McBride, 2018).

\footnotetext{
${ }^{x}$ ADM 7/827; ADM 2/1733; AND 28

xi ADM 7/216; ADM 7/639

xii Viz is still widely used in modern English, it is an abbreviation for the latin 'videlicet' which means 'namely'

xii There are some abbreviations in this and the following table which relate to the monetary and weight system at the time - money was in pounds sterling (f), shillings (s) and pence (d) and the weights were in pounds (lb).
} 